\title{
SUSTAINABLE DEVELOPMENT AND THE NATURE OF ENVIRONMENTAL LEGAL PRINCIPLES
}

J Verschuuren $^{*}$

\section{Introduction}

Since the 1992 Rio Conference on Environment and Development (UNCED), environmental legal principles, such as the precautionary principle, the polluterpays principle or the principle of public participation, play an ever-increasing role in international and national environmental law and policy, as does the concept of sustainable development. The concept of sustainable development has become the leading concept in environmental policies around the world. The principles included in the Rio Declaration on Environment and Development ${ }^{1}$ are applied in many international environmental treaties and are codified in national legislation. Further endeavours to promote principles of environmental law in the international community are carried on with such draft documents as the Earth Charter $^{2}$ by the Earth Council and the IUCN International Covenant on Environment and Development. ${ }^{3}$ With all these rapid developments in international and national environmental law, it becomes increasingly necessary to more precisely determine what is the legal function of the concept of sustainable development, which I will later call an "ideal", and of the principles of environmental law. What is the relationship between the ideal of sustainable development and the legal principles and more concrete environmental legal rules, and between the principles and the rules? There is a

* Prof Dr J Verschuuren, Professor of European and International Environmental Law, Tilburg University, The Netherlands, and member of the Netherlands Advisory Council for Housing, Spatial Planning and the Environment, director of the Centre for Legislative Studies of the Schoordijk Institute for Jurisprudence and Comparative Law (Tilburg University) and a member of the Commission on Environmental Law of the IUCN as well as a member of the board of the Netherlands Committee of the IUCN.

1 UN Doc. A/CONF. 151/26/REV. 1/Vol. 1 (1992), reprinted in 1992 ILM 876.

2 Earth Charter Commission http://www.earthcharter.org 14 Feb, adopted in March 2000.

3 IUCN http://iucn.org/themes/law/cel07.html 14 Feb (draft). 
lot of misunderstanding and confusion on this subject, as has been stated rather clearly by Howard Mann: ${ }^{4}$

It is difficult to enter into a discussion on principles of international law for sustainable development without a sense of [...] confusion. [...] Confusion, because perceptions of the nature, status, role and substance of principles have become increasingly unclear in the post-Rio period.

Although environmental legal principles have the longest history in the field of international law, the question of what the consequences of the difference between principles and rules for real cases are has not yet been addressed in much detail by international courts and tribunals. ${ }^{5}$ There are some cases where principles of environmental law did play a (marginal) role, ${ }^{6}$ but a principle judgement on the character of principles cannot be found in this field of law. On the contrary, in international policy and law, there is a great deal of misunderstanding about principles. This was shown, for instance, when the UN Framework Convention on Climate Change 1992, was concluded. The United States consistently opposed inclusion of an article on principles in the convention, arguing that principles only state the intentions of the parties and provide a context for interpreting the commitments and that they, therefore, should be included in the preamble only. If the principles were commitments, they should be included in the convention as legal rules. Such a vision on principles underestimates their role in legal practice and, more in general, fails to appreciate the legal meaning of principles and the basic difference between principles and legal rules. $^{7}$ In its extensive work on "Legal Principles for Environmental Protection and Sustainable Development", the Experts Group on Environmental Law of the World Commission on Environment and

4 Mann "Comment on the Paper by Philippe Sands" 71.

5 Sands "International Law in the Field of Sustainable Development" 54.

6 See for instance the Case concerning the Gabcikovo-Nagymaros Project 199837 ILM 162 before the International Court of Justice in which Hungary relied heavily upon the precautionary principle, and the case of Balmer-Schafroth v Switzerland ECHR 26 August 1997 Rep 1997-IV, in which only in dissenting opinions the precautionary principle played a (small) part. See on the latter: Craven 1998 RECIEL 1-95.

7 Bodansky 1993 Yale J of International Law 501-502. 
Development (WCED) has not addressed the question of the legal status of these principles at all. ${ }^{8}$

This lack of attention for the legal status of principles is not typical of international environmental law only. The European Court of Justice was willing to test against environmental legal principles laid down in the EC Treaty (the present article 174 , formerly article 130R) only in a small amount of cases. ${ }^{9}$ The EC-legislator does not systematically refer to these principles in environmental directives or regulations. In national environmental law, things are not much different. Although the legislator, in many countries all over the world, is now in the process of explicit codification of environmental legal principles, a substantive discussion on the question what is the purpose of such a codification is very often refrained from. ${ }^{10}$

The confusion is partly caused by the fact that many norms or policy statements are called "principles". The frequent and often irrational use of the word "principle" has given it a rather unclear status. Highly abstract notions like sustainable development or biodiversity, but also human rights and procedural rules on environmental impact assessment: we can retrace them all as "principles" in the various declarations and treaties of the international community, most notably in the 1972 Stockholm Declaration on the Human Environment and the 1992 Rio Declaration on Environment and Development. $^{11}$

In this article, I would like to get a grip on the "things" lawyers call "principles" of environmental law. For a long time, a principle was considered to be a special

8 Experts Group on Environmental Law Environmental Protection.

9 The Safety Hi-Tech cases of 14 July 1998 were only the first examples of such willingness to test against the principles of environmental law laid down in a 130R of the EC-Treaty, Cases C-284/95 and C-341/95 (CURIA http://curia.eu.int 18 Apr).

10 An example is the codification of environmental law in Belgium, where those that drafted the principles only gave reasons for the content of the principles, not for their inclusion in the new environmental legislation, Draft Decree on Environmental Policy for the Flemish Region, reprinted in Bocken and Ryckbost (eds) Codification of Environmental Law 161163.

11 UN Doc A/CONF 48/14/REV 1 (1972) and UN Doc A/CONF151/26/Rev 1/Nol I (1992), reprinted in 1992 ILM 876. 
kind of norm, characterized by a rather general meaning, differentiating it from the more concrete legal rules. Principles go beyond concrete rules or policy goals; instead, they say something about a group of rules or policies, they denote what a collection of rules has in common, or what the common goal is of a collection of rules (for instance a statute). Principles usually contain a high moral and/or legal value.

This, however, leaves at least three fundamental questions unanswered:

1. Where does this high moral value come from?

2. What is the exact difference between a principle and a legal rule, and between a principle and a policy?

3. What is the relationship between a principle and more concrete legal rules and policies?

The first question is the most difficult one. Fuller has convincingly shown that in law, a distinction must be made between the morality of duty and the morality of aspiration. ${ }^{12}$ The morality of duty

...lays down basic rules without which an ordered society is impossible, or without which an ordered society directed toward certain specific goals must fail of its mark. ${ }^{13}$

The "principles"14 of a morality of aspiration are

...loose, vague, and indeterminate, and present us rather with a general idea of the perfection we ought to aim at, than afford us any certain and infallible directions acquiring it. ${ }^{15}$

12 Fuller Morality of Law $5 \mathrm{ff}$.

13 Fuller Morality of Law 5-6.

14 Although Fuller uses the word "principle" here, I wish to reserve the term "principle" for legal principles, not for ideals or values as in the sense of Fuller's "principles of the morality of aspiration". Selznick Moral Commonwealth 438 does not make a clear distinction between principles and values either. He calls legal principles "legally recognized values".

15 Fuller Morality of Law 6. 
In more modern terms, such values could be described as the ideals of society or of a more specific community. In the next paragraph, I will try to show that in these ideals the basis for legal principles can be found (paragraph 2).

In paragraphs 3 and 4, the second and third questions will be dealt with. Basically, I will start from Dworkin's ${ }^{16}$ distinction between rules, principles, and policies and elaborate on this distinction a little further, taking examples from the field of environmental law.

In paragraph 5 of this article, I will have a closer look at the specific character of the field of environmental policy and law. Since the ideal of sustainable development is of a rather anthropocentric nature, the question arises whether this ideal can actually be fit to be the goal that should be reached through applying legal principles and rules.

For reasons of clarity, I wish to point out that the subject of this article is principles of environmental law. A distinction can be made between general principles of law, being principles that are valid for all fields of law (for example the principle of equality of arms), and legal principles that are valid for a specific field of the law, i.e. environmental law. Although I realise that not all writers make this distinction in their thinking and writing about principles (especially in the Anglo-American literature), I draw from their writings as well. ${ }^{17}$ The character of this article is that of legal theory. I will not go into the meaning of any specific environmental legal principle for legal practice, such as the precautionary principle, the prevention principle, or the polluter pays principle. ${ }^{18}$

16 Dworkin Model of Rules I $22 \mathrm{ff}$.

17 Most writers only mention general legal principles. Selznick Moral Commonwealth 431432, for instance, mentions the principles of entitlement, justification, equality, impartiality, proportionality, reciprocity, rectification, need, desert, and participation.

18 There are many publications that do just that. Highly recommended in this respect is De Sadeleer Environmental Principles, who goes into these three principels in great detail. 


\section{$2 \quad$ From ideals to principles}

\subsection{The pursuit of ideals: sustainable development}

Ideals have been defined as

...values that are implicit or latent in the law, or the public and moral culture of a society or group that usually cannot be fully realized, and that partly transcend contingent, historical formulations, and implementations in terms of rules and principles. ${ }^{19}$

It is clear that this definition of an ideal is not very different from the morality of aspiration, as formulated by Fuller. Ideals are an expression of the morality of aspiration, without direct relevance to the law. They are vague ideas about what is morally the best thing to do. This can only be a vague idea, since we do not know what is perfectly good human conduct. ${ }^{20}$ We do not want "to pin (a man) to the wall with the final articulation of his highest good", we do "know enough to create the conditions that will permit a man to lift himself up". ${ }^{21}$ What we want with the formulation of an ideal is to show what, in the end, is the ultimate goal of society, or, as Fuller puts it:

One of the highest responsibilities of the morality of aspiration is to preserve and enrich (the) social inheritance. $^{22}$

A well-known example of an ideal in the field of environmental policy is the ideal of sustainable development. ${ }^{23}$ The idea of sustainable development as an ideal for future environmental policy originated in the early 1970s. Illustrative in this

19 Van der Burg 1997 Journal of Value Inquiry 25, and Van der Burg Morality of Aspiration 176. Alexy Zum Begriff des Rechtsprinzips 81 has a somewhat different definition, emphasizing legal norms rather than values: "(...) jedes Sollen, das nicht voraussetzt, daß das, was gesollt ist, in vollem Umfang tatsächlich und rechtlich möglich ist, das dafür aber möglichst weitgehende oder approximative Erfüllung verlangt."

20 Fuller Morality of Law 10.

21 Fuller Morality of Law 12.

22 Fuller Morality of Law 13.

23 I will call the idea of sustainable development an ideal or a value. I will later on in this section and in the next show why this idea can be seen as an ideal. It is also possible to apply my theory on the relationship between an ideal and legal principles on the ideal of the conservation of biodiversity, cf Verschuuren and Oudenaarden The Role of Ideals 231262. 
respect is the last paragraph of the famous "A Blueprint for Survival" by Goldsmith and others: ${ }^{24}$

Our task is to create a society which is sustainable and which will give the fullest possible satisfaction to its members. Such a society by definition would depend not on expansion but on stability. This does not mean to say that it would be stagnant Cindeed it could well afford more variety than does the state of uniformity at present being imposed by the pursuit of technological efficiency. We believe that the stable society [...], as well as removing the sword of Damocles which hangs over the heads of future generations, is much more likely than the present one to bring peace and fulfilment which hitherto have been regarded, sadly, as utopian.

The idea of sustainable development really came into fashion in 1987 with the publication of the report of the World Commission on Environment and Development "Our Common Future". In this report, sustainable development was described as

...a process of change in which the exploitation of resources, the direction of investments, the orientation of technological development and institutional change are all in harmony and enhance both current and future potential to meet human needs and aspirations. $^{25}$

The work of the WCED was inspired by an urgent call of the General Assembly of the United Nations to

...help define shared perceptions of long-term environmental issues and the appropriate efforts needed to deal successfully with the problems of protecting and enhancing the environment, a long-term agenda for action during the coming decades and aspirational goals for the future. ${ }^{26}$

The WCED has clearly come up with such an aspiration: man is responsible for the future of the earth. Today's generation may not fulfil its needs while endangering the possibility for future generations to fulfil their needs. And also, environmental problems related to the (economical and technical) development 
of developed countries may not hamper the possibilities of developing countries to strive for (economical and technical) development as well. ${ }^{27}$ With the introduction of the concept of sustainable development, economic development, the environment, and human rights are treated in an integrated and interdependent manner. ${ }^{28}$

To reach this goal, the WCED made several proposals for institutional and legal change, so that the ecological dimensions of policy be considered at the same time as the economic, trade, energy, agricultural, industrial, and other relevant dimensions. ${ }^{29}$ Legal change means, among other things, that sustainable development objectives are incorporated in all governmental (legislative and administrative) actions on a national level, worldwide (I later will call this "(external) integration", cf section B). ${ }^{30}$ Also, risks of irreversible damage to the environment must be assessed and diminished (the precautionary approach, cf section B). ${ }^{31}$ Thirdly, the role of NGOs and private and community groups in environmental policy must be recognized and strengthened. ${ }^{32}$ Such policy goals (the WCED report mentions many more) can be seen as an effort to make the rather abstract ideal of "sustainable development" more concrete. The same is done by the formulation of legal principles by a working group of the WCED, included in the report of the WCED itself. I will elaborate on these in the next two sections.

Since the publication of the WCED report, the idea of sustainable development, as an ideal, has been firmly recognised in non-binding UN declarations, as well as in many national or supranational legal documents. For instance, since the changes made by the Maastricht Treaty, article 2 of the EC-Treaty mentions the achievement of sustainable development a fundamental objective of the

27 Some consider the fact that developing countries were able to influence international environmental norms to this extent UNCED's most important step forward, Porras Rio Declaration 33.

28 Sands "International Law in the Field of Sustainable Development" 53.

29 WCED Our Common Future 313.

30 WCED Our Common Future 314.

31 WCED Our Common Future 323.

32 WCED Our Common Future 328. 
European Union. ${ }^{33}$ In the Belgian Act on Environmental Policy, sustainable development has been laid down as the main goal of environmental policy, ${ }^{34}$ which is the case in many other countries as well. Article 4 of the Japanese Basic Environmental Law of 1993, for instance, states: ${ }^{35}$

Environmental conservation shall be promoted so that a society can be formulated where the healthy and productive environment is conserved and sustainable development is ensured by fostering sound economic development with reduced environmental load [...].

By 1992, when the United Nations Conference on Environment and Development (UNCED) took place in Rio de Janeiro, sustainable development had become an ideal that no one could ignore. All the documents signed at the Rio Conference state, in one way or another, that everything that had been agreed on was necessary in order to reach sustainable development. The preamble to Agenda 21, for instance, starts with the following lines: ${ }^{36}$

Humanity stands at a defining moment in history. We are confronted with a perpetuation of disparities between and within nations, a worsening of poverty, hunger, ill health and illiteracy, and the continuing deterioration of the ecosystems on which we depend for our well-being. However, integration of environment and development concerns and greater attention to them will lead to the fulfilment of basic needs, improving living standards for all, better protected and managed ecosystems and a safer, more prosperous future. No nation can achieve this on its own; but together we can $B$ in a global partnership for sustainable development.

The Rio Declaration on Environment and Development, which was concluded during the UNCED as well, states in Principle $1:^{37}$

Human beings are at the centre of concerns for sustainable development. They are entitled to a healthy and productive life in harmony with nature.

33 Treaty establishing the European Community as amended by the Treaty of Amsterdam 1997 Offical Journal C 304/173 ff.

34 A 1.2 .1 ' 1 of the Law of 5 April 1995, Belgian Bulletin of Acts and Orders of 3 June 1995, reprinted in Bocken and Ryckbost (eds) Codification of Environmental Law.

35 A 4 Law No 91 of 1993 (translation: Japanese Ministry of the Environment).

36 UN Doc A/CONF 151/26/Vol I-III reprinted in Johnson Earth Summit 129.

37 UN Doc A/CONF 151/26/REV 1/Vol 1 1992, reprinted in 1992 ILM 876. 
Apart from these very general (non-binding) international documents, the ideal of sustainable development can also be found in more concrete (binding) treaties, like the Kyoto Protocol to the United Nations Framework Convention on Climate Change of 11 December 1997. Article 2 of this Protocol reads: ${ }^{38}$

Each Party included in Annex I, in achieving its quantified emission limitation and reduction commitments under Article 3, in order to promote sustainable development, shall: (a). ... etc.

The Kyoto Protocol then gives more concrete rules, the most important being that overall emissions of greenhouse gases should be reduced by each of the parties to the Protocol by 5 per cent, relative to 1990, in the period 2008 to 2012, followed by rules on monitoring, on review teams, and on a "clean development mechanism" to help parties not included in Annex I (developing countries that could not agree to a certain emission reduction target) in

...achieving sustainable development and in contributing to the ultimate objective of the Convention, and to assist Parties included in Annex I in achieving compliance with their quantified emission limitation and reduction commitments. ${ }^{39}$

At the European level, the ideal of sustainable development has been explicitly mentioned in various EC Directives. Directives very often state in their preamble that the provisions are necessary to promote "the principle of sustainable development". The Council Directive concerning Integrated Pollution Prevention and Control ${ }^{40}$ (IPPC) gives concrete rules on permits for certain branches of industry. Certain installations, in, for instance the energy, mineral, metal or chemical industries, can only be operated after a permit has been granted. The permit must include requirements ensuring that a high level

38 FCCC/CP/1997/7/Add 1, reprinted in 1998 ILM 22.

39 A 3(1), 4, 6 and 12 open up the possibility of so-called "joint implementation", although this term itself was dropped during the process of negotiation, cf Breidenich et al 1998 AJIL 324-325.

40 Council Directive 96/61/EC of 24 September 1996 concerning Integrated Pollution Prevention and Control 1996 Official Journal L 257/26. 
of protection is given to the environment as a whole. The ultimate goal is to promote sustainable development. $^{41}$

Another recent example is the Directive on Ambient Air Quality Assessment and Management, which, in its preamble describes one of the goals to be reached as follows:

In zones and agglomerations where the levels of pollutants are below the limit values, Member States must endeavour to preserve the best ambient air quality compatible with sustainable development. ${ }^{42}$

The concrete rules in this Directive concern limit values for certain pollutants, to be set by the European Commission, which have consequences for those zones where the levels of these pollutants are higher than the limit levels. In areas where the levels are lower

...Member States shall maintain the levels of pollutants in these zones and agglomerations below the limit values and shall endeavour to preserve the best ambient air quality, compatible with sustainable development. ${ }^{43}$

Note that in this Directive the ideal of sustainable development is included in a concrete rule as well. I will go into this matter in paragraph 4.

Although sustainable development is sometimes referred to as a "principle" (cf Principle 1 of the Rio Declaration, article 3(1) of the UN Framework Convention on Climate Change, and the IPPC Directive, mentioned above), ${ }^{44} \mathrm{I}$ think it is

41 The preamble states under no 9: "Whereas this Directive [...] lays down the measures necessary to implement integrated pollution prevention and control in order to achieve a high level of protection for the environment as a whole; whereas application of the principle of sustainable development will be promoted by an integrated approach to pollution control; [...]". Note that the word "principle" is used here to denote the ideal of sustainable development. I will go into this below and in s 2.2 of this paragraph.

42 Council Directive 96/62/EC of 27 September 1996 on Ambient Air Quality Assessment and Management 1996 Official Journal L 296/55.

43 A 9 of Directive 96/62/EC.

44 For the IPPC Directive, see above and $n$ 29. See for an example in the literature Nollkaemper Legal Regime for Transboundary Water Pollution 82. 
safe to call the goal of sustainable development an ideal. ${ }^{45}$ Looking at Fuller's morality of aspiration, it is true that the ideal of sustainable development, as formulated in the various legal documents, does not lay down basic rules without which an ordered society is impossible, or without which an ordered society directed toward certain specific goals must fail of its mark (morality of duty), but instead, that it is a loose, vague, and indeterminate, general idea of the perfection we ought to aim at. We, as well as generations to come, will need to aspire to reach the goal of sustainable development, without anticipating reaching it. ${ }^{46}$

Van der Burg's definition of an ideal, however, only partly fits the above description of the value of sustainable development. It is true that sustainable development is a value that cannot be fully realised and that partly transcends contingent, historical formulations and implementations in terms of rules and principles. On the other hand, however, the "ideal" of sustainable development has been laid down in various important legal documents, not as rules or legal principles, but as an ideal. Thus, either "sustainable development" is an ideal, but then the definition has to be changed to: "values that are explicit, implicit or latent in the law, ... etc.", or "sustainable development" is not an ideal but a (legal) principle.

The latter position seems to be supported by the wording of the Rio Declaration (see above). Still, in the next section I will argue that "sustainable development" is an ideal and not a principle.

\subsection{The relationship between ideals and principles}

In the previous section, I have shown that the idea of sustainable development is a vague and undeterminate goal society aims at to reach perfection; a goal of

45 Although Sands "International Law in the Field of Sustainable Development" 57-58 calls sustainable development a "legal principle", he also shows that there are "principles underlying the concept of sustainable development", showing that the concept of sustainable development is much more than a legal principle.

46 Mann Comment on the Paper by Philippe Sands 71. 
high moral standard that the entire world community has embraced. To promote this goal, that never can be fully reached, a call upon the morality of duty must be made. In other words: more concrete economic, legal, and social instruments must be brought into action to generate a more sustainable use of the resources of the Earth.

In this article I focus on the legal instruments. ${ }^{47}$ I will show that a first step to make the ideal more concrete is the formulation of (legal) principles, and that, in order to apply these principles, certain (even more concrete) rules are developed.

Principles can be seen as the link between ideals and duties, between the morality of aspiration and the morality of duty, between values and rules. ${ }^{48}$ Principles can be part of written, formal law, can be part of legislation and treaties, can, together with more concrete rules (in combination with those rules) impose duties on the state or on individuals. On the other hand, principles themselves do not comprise enforceable legal duties. ${ }^{49}$ They do, however, shed more light on the (moral) targets of legislative rules and thus form the link between the morality of aspiration and the morality of duty. Principles are a necessary medium for ideals to find their way into concrete rules. They can be used to bridge the gap between the morality of duty and the morality of aspiration. Because of their basis in (written or unwritten) law and their possible direct and intense influence on legal rules concerning activities that may harm the environment, they must be placed within the morality of duty: a bridgehead within the morality of duty reaching out for the morality of aspiration..$^{50}$

47 Besides legal instruments, social and economic instruments can be important as well in the realisation of environmental policy objectives. Many of such instruments have also been included in international environmental treaties, like emissions trading and other market-based mechanisms in the Kyoto Protocol, cf Breidenich et al 1998 AJIL 323-325.

48 MacCormick 1974 Law Quarterly Rev 127; Selznick Moral Commonwealth 439.

49 It must be acknowledged, however, that this distinction is not a very strict one: there is a sliding scale with a theoretical abstract and undeterminate principle on one side and a very concrete, highly practical rule on the other. See further in par 3 under 3.1.

50 Contrary to Van der Burg Morality of Aspiration 179, who argues that principles and policies, together with ideals, all are categories of the sphere of aspiration, leaving only legal rules in the sphere of duty. 
Legal principles have long played an important role in the law. Without going into the role of principles too deeply now (cf. paragraph 3), I wish to point at three main functions of legal principles:

1. Principles fill in open or unclear rules; they can be used in the process of interpreting rules in concrete cases by administrative authorities as well as by the courts; or in the words of Selznick: a principle is a window to justice. $^{51}$

2. Principles form the basis for new (national and EU) legislation or (international) treaties;

3. Principles form the basis for self-regulation or otherwise help to determine how private parties should behave in the social order.

For now, I would like to take the position that principles are part of written, statutory law and that they can be invoked in court and thus form a part of the morality of duty, albeit they are of a more normative and abstract nature than legal rules. The ideals or values behind these principles form the morality of aspiration, sustainable development being the prime example in the field of environmental law. ${ }^{52}$

If we accept this thesis, it is obvious that such an ideal makes itself felt above all in the more abstract norms within the legal systems: the legal principles. Vague and indeterminate as ideals are, it is not very well understandable that they directly influence concrete legal rules like procedural rules for decisionmaking or for appeal, or substantive rules like the exact limit value for $\mathrm{SO}_{2}$ emissions.

51 Selznick Moral Commonwealth 440.

52 Contrary to Alexy Zum Begriff des Rechtsprinzips 81, who states that principles themselves are ideals that can never be fully realised. Alexy, however, does point at a difference between an "ideales Sollen" and a "reales Sollen"; "ideales Sollen" is very much comparable to my definition of an ideal (cf $s$ 2.1); whenever duties or norms are recognised, one can speak of "'reales Sollen". The latter position appears to correspond more to my own. 
Ideals, however, are, as far as their nature and functions are concerned, more comparable to legal principles. Principles, as we have already seen, go beyond concrete rules or policy goals; instead they say something about a group of rules or policy goals, they indicate what a collection of rules has in common, or what the common goal is of a collection of rules (for instance a statute). Principles usually contain a high moral and/or legal value. Principles thus form a first attempt to make ideals more concrete.

Although the character of ideals and principles may seem somewhat alike, there is a fundamental difference. Legal principles are important norms that, although different in nature from legal rules, can be applied in day-to-day legal practice, and thus form a part of the morality of duty. Later on in this essay I will show the relevance of principles for concrete administrative decisions, like the decision on granting a permit, and for concrete judicial decisions, like the judgement on whether or not the government did rightfully allow drilling for oil in an area of great ecological value. While principles can be directly applied in the law, this is not the case with ideals, like the ideal of sustainable development. This ideal is so vague and abstract ${ }^{53}$ that the legislator and other actors in legal processes need to clarify it by making and applying principles and rules. It therefore is not very useful to call this ideal a "principle". ${ }^{4}$ The ideal of sustainable development simply cannot serve as a beacon indicating the direction legal development should take because profound differences of opinion exist with regard not only to the means by which these goals are to be reached, but also the exact meaning of the goals themselves. ${ }^{55}$

53 Kidd 1992 Journal of Agricultural \& Environmental Ethics 1-26 has shown that the idea of sustainable development was compiled of six separate strains of thought that are widely diverse and incompatible, which explains the vagueness and the difficulty to apply the idea in practice.

54 Although I find his example of the "principle of informed consent" (which looks more like a rule to me) not very convincing, I agree with Van der Burg 1997 Journal of Value Inquiry 26 that it is not useful to transform an ideal into a very vague and broad principle that is of little practical use. Unfortunately, the ideal of sustainable development is sometimes called a "principle", as was shown above (s 2.1).

55 See further on this matter Verschuuren and Oudenaarden Role of Ideals 235-240. 
How then does an ideal affect legal principles? Let's return to the ideal of sustainable development to find an answer to this question.

At the international level, there are many treaties, declarations, and policy documents in which the value of sustainable development is put forward as the ultimate goal of that specific treaty. More general documents like the (nonbinding) Rio Declaration and Agenda 21 contain a lot of principles that have to be achieved in order to reach a sustainable society. ${ }^{56}$ While Agenda 21 is a policy document which refers to relevant principles when necessary, the Rio Declaration is a true catalogue of environmental legal principles that are considered by the world community to be important for environmental and development policy and law. Many of the principles state that they have to be promoted in order to achieve a sustainable society (literally so in Principles 3, 4, $5,8,9,12,20,21,22,24$ and 27). The WCED, too, has adopted a set of legal principles; they are included in the report "Our Common Future". ${ }^{57}$ As mentioned above, it was this report that worked as a catalyst in making the ideal of sustainable development a flourishing ideal in the international community. The WCED principles, which, according to the mandate of the Experts Group that drafted the "Legal Principles for Environmental Protection and Sustainable Development", ought to be in place "to support [...] sustainable development", include such principles as the co-operation principle (Principle 8):

States shall co-operate in good faith with other States in implementing the preceding rights and obligations.

56 Bodnarek Concept of Sustainable Development 102-106 states rather loosely that these are "the guiding principles of sustainable development". He seems to suggest that realisation of all of the Rio Principles leads to sustainable development. Schröder Sustainable Development and Law 5 has more or less the same approach.

57 A "Summary of the Proposed Legal Principles for Environmental Protection and Sustainable Development adopted by the WCED Experts Group on Environmental Law" was included as Annex 1 in the report, WCED Our Common Future $348 \mathrm{ff}$. The Final Report of the Experts Group itself (with slightly differently formulated principles, dated June 1986) has been published seperately (Experts Group on Environmental Law Environmental Protection). 
And the principle of prevention ${ }^{58}$ and abatement (Principle 10):

States shall prevent or abate any transboundary environmental interference which could cause or causes significant harm [...].

Examples from the Rio Declaration are the precautionary principle (Principle 15):

In order to protect the environment, the precautionary approach shall be widely applied by states according to their capabilities. Where there are threats of serious or irreversible damage, lack of full scientific certainty shall not be used as a reason for postponing costeffective measures to prevent environmental degradation.

And the principle of integration (Principle 4):

In order to achieve sustainable development, environmental protection shall constitute an integral part of the development process and cannot be considered in isolation from it.

These principles can be found in more specific (binding) treaties as well. The 1992 Helsinki Convention on the Protection and Use of Transboundary Watercourses and International Lakes states in article 2(5): ${ }^{59}$

The parties shall be guided by the precautionary principle, by virtue of which action to avoid the potential transboundary impact of the release of hazardous substances shall not be postponed on the ground that scientific research has not fully proved a causal link between those substances, on the one hand, and the potential transboundary impact, on the other hand; [...]

Or, on the same principle, the Convention for the Protection of the Marine Environment of the North East Atlantic, article 2(2): ${ }^{60}$

The contracting Parties shall apply the precautionary principle, by virtue of which preventive measures are to be taken when there are

58 The word "could" also indicates the precautionary principle. In the Final Report of the Experts Group on Environmental Law Environmental Protection 79, the words "significant risk" were used instead of "could". According to the comment on this principle, certain dangerous activities will no longer be considered unlawful when all possible precautionary measures have been taken to preclude the materialisation of the risk. See Backes and Verschuuren 1998 Colorado J of International Environmental Law and Policy 58.

591992 ILM 1312.

601992 ILM 1069. 
reasonable grounds for concern that substances or energy introduced, directly or indirectly, into the marine environment may bring about hazards to human health, harm living resources and marine ecosystems, damage amenities or interfere with other legitimate uses of the sea even when there is no conclusive evidence of a causal relationship between the inputs and the effects.

Very often, the principles of environmental law are more or less "hidden" in more concrete rules. Especially in the more detailed treaties, we find them hidden in subordinate clauses, like the principle of "common but differentiated responsibilities" (Principle 7 of the Rio Declaration) in article 10 of the Kyoto Protocol:

All parties, taking into account their common but differentiated responsibilities and their specific national and regional development priorities, $[\ldots]^{61}$

The same situation (i.e. principles being codified as a principle or "hidden" in more concrete legal rules) can be observed at the European and at national levels. Already since 1987, important principles of (EC) environmental law have been codified in the EC Treaty. ${ }^{62}$ Currently, article 174(2), in which the principles of precaution, prevention, rectification at source, and the "polluter pays" principle have been included, reads as follows:

Community policy on the environment shall aim at a high level of protection taking into account the diversity of situations in the various regions of the Community. It shall be based on the precautionary principle and on the principles that preventive action should be taken, that environmental damage should as a priority be rectified at source and that the polluter should pay.

The principle of integration has been explicitly laid down in the Chapter entitled "Principles", in article 6 of the Treaty: ${ }^{63}$

61 Other examples in the Kyoto Protocol are the precautionary principle (a 3(4), "taking into account uncertainties"), and the principle of cooperation and transfer of technologies (a 10), both of which can be found in the Rio Declaration as well (Principles 15 and 9 respectively).

62 Treaty establishing the European Community as amended by the Treaty of Amsterdam 1997 Offical Journal C 304/173 ff.

63 Id. 
Environmental protection requirements must be integrated into the definition and implementation of the Community policies and activities referred to in Article 3, in particular with a view to promoting sustainable development.

The Council Directive concerning Integrated Pollution Prevention and Control ${ }^{64}$ (IPPC) states it is in compliance with the "polluter pays" principle and the principle of pollution prevention (consideration no 1), while article 3(a) of the Directive prescribes that measures to control pollution must be in accordance with the principle of best available techniques. Although not explicitly mentioned, the precautionary principle plays a role in the Directive since Article $3(f)$ states that

...the necessary measures are taken upon definitive cessation of activities to avoid any pollution risk and return the site of operation to a satisfactory state.

In the preamble of the revised Council Directive on the Assessment of the Effects of Certain Public and Private Projects on the Environment, ${ }^{65}$ to take just another example of an important environmental directive, it is considered that the Directive on environmental impact assessment is necessary since,

...pursuant to article 130r (2) of the Treaty (old numbering, JV), Community policy on the environment is based on the precautionary principle and on the principle that preventive action should be taken, that environmental damage should as a priority be rectified at source and that the polluter should pay.

In national legislation, principles have also been laid down in statutes, and there are ongoing discussions on the codification of principles of environmental law. In the Flemish Region in Belgium, the same principles mentioned in article 174 of the EC Treaty have been laid down, after the goals for environmental

64 Council Directive 96/61/EC of 24 September 1996 concerning integrated pollution prevention and control 1996 Official Journal L 257/26.

65 Council Directive 97/11/EC of 3 March 1997 amending Directive 85/337/EEC on the assessment of the effects of certain public and private projects on the environment 1997 Official Journal L 073/55. 
policy have been formulated (goals that have to be promoted for the benefit of present and future generations). ${ }^{66}$ The first goal is: "to manage the environment by means of the sustainable use of natural resources [...]". ${ }^{67}$ In Germany, a proposal has been made for the codification of three important environmental legal principles: the precautionary principle, the "polluter pays" principle and the co-operation principle. ${ }^{68}$ These principles already play an important role in German environmental law. Since the early 1970s, the precautionary principle is the key principle in discussions on the Emissions Control Act and the Nuclear Energy Act. Like in the Flemish Decree, in the German proposal, targets for an environmentally sound development have been laid down as well; objectives that have to be promoted because of the responsibility for future generations. ${ }^{69}$ In France, general principles of environmental law were codified in 1995, including (among other things) the precautionary principle, the "polluter pays" principle, and the principle of participation. ${ }^{70}$ In Australia environmental legal principles, such as the precautionary principle and the principle of intergenerational equity, have been codified in the Environment and Biodiversity Conservation Act 1999. Since then, especially the precautionary plays a major role in Australian case law. ${ }^{71}$

$66 \quad \mathrm{~N} 34$ above A 1.2.1' 1.

$67 \mathrm{~N} 34$ above A 1.2.1 ' 1. The principles have been laid down in a 1.2.1 '2.

68 Bundesministerium für Umwelt, Naturschutz und Reaktorsicherheit, Entwurf Umweltgesetzbuch (UGB-KomE), 1997. The "polluter pays" principle has been formulated as "Verursacherprinzip" (perpetrator principle), giving it a wider meaning than just "the polluter pays". Cf, among many others, Sendler 1996 Neue Zeitschrift für Verwaltungsrecht 11451151.

69 § 4: "Der Schutz der Umwelt und des Menschen ist, auch in Verantwortung für die künftigen Generationen, insbesondere dadurch zu gewährleisten, daß: (...)".

70 Loi 95-101 du 2 février 1995 relative au renforcement de la protection de l"environnement. See Jégouzo 1995 RFD adm 12(2) 209-217. The text of the principles is reprinted in an article by Cans 1995 Revue Juridique de l"Environnement 195-217.

71 Environment and Biodiversity Conservation Act 91 of 1999. See Fisher and Harding Precautionary Principle in Australia 215-233. For a more detailed discussion of the situation in Australia, Germany, The Netherlands, Belgium and Finland, see Verschuuren Principles of Environmental Law 109-128. 


\subsection{Principles and principles}

I already showed that sometimes an ideal is called a "principle" and that this is not very useful. On the other side of the spectrum, there can be misunderstanding on the difference between principles and concrete legal rules. These misunderstandings originate from the different character of different principles. Not all the "things" lawyers call principles can be seen as the above-mentioned link between ideals and concrete legal rules. Some principles are more principle than others. Some principles form a beachhead of law and ethics: ${ }^{72}$ they help us discover the foundations for decisions to be taken and judgements to be made. ${ }^{73}$ Others are less abstract, more like rules. Individual legal principles can be put on a sliding scale, from very abstract and of a high morality, to very concrete and precise; they cover almost all the space between an ideal, on the one hand, and a rule, on the other.

Take, for instance the principle that

Man has the fundamental right to freedom, equality and adequate conditions of life, in an environment of a quality that permits a life of dignity and well-being, and he bears a solemn responsibility to protect and improve the environment for present and future generations (...)' (Principle 1 of the 1972 Stockholm Declaration on the Human Environment) ${ }^{74}$

And the principle that

Environmental impact assessment, as a national instrument, shall be undertaken for proposed activities that are likely to have a significant adverse impact on the environment and are subject to a decision of a competent national authority (Principle 17 of the 1992 Rio Declaration).

The first principle has a higher "morality of aspiration" character than the second one. While the first principle sets a vague and indeterminate goal,

72 Vranken Algemeen Deel 86.

73 Scholten Rechtsbeginselen 270.

74 N 11 above. 
without giving the one perfect way of reaching it, the second one is much closer to day-to-day legal practice. It has much more the character of the morality of duty, and, one could argue, has almost reached the status of a legal rule, i.e. the rule saying that the contracting State must set up a system of environmental impact assessment. One could even argue that the latter is not a principle at all, but a concrete legal rule. In the field of environmental law alone, there are dozens of principles giving direction to legal decisions, such as the granting of a permit by a governmental authority, a court decision on a case between a polluter and an environmental action group, the issuing of legislation by the national or lower legislator. Do all these "things" that are called principles have to have the same role in law?

It cannot be denied, that in negotiation processes on environmental treaties or declarations with many nations involved, principles, because of their vague character and because of the fact that they are not directly legally binding, can be agreed upon more easily. Mann correctly noted that sometimes principles have more meaning and impact as a record of the political bargains that underlie a Convention, than as hard or soft-law obligations in themselves. ${ }^{75}$ When looking at "things" that are called principles, this must be kept in mind.

In the end, I think there are four arguments, to explain the difference in the character of principles:

1. principles can take various forms, varying from very abstract to very precise, and from a high morality of aspiration to a high morality of duty;

2. people who draft laws and treaties are not aware of the character of principles and make legal rules which they inaccurately call principles;

3. people who draft laws and treaties are aware of the character of principles, but because of the failure to conclude to legally binding rules, they call the rules "principles", indicating the non-binding character of the rules;

4. a combination of the above. 
In my opinion, the fourth possibility is the most likely one, considering national and international environmental legal practice today. The consequence of this observation is that it is essential that each principle must be valued in its own respect. The more concrete a principle is, the more it can be treated as a rule and the easier it is to directly apply it in a concrete case.

Without going too deeply into the matter of the degree to which principles are legally binding (the rest of the essay deals with that question), it has to be noted that, although there are as many differences as there are principles, Dworkin's theoretical distinction between principles and rules remains in tact. Generally it can be said that principles "state a reason that argues in one direction, but does not necessitate a particular decision"; ${ }^{76}$ the direction they point at is a desirable direction because of "justice, or fairness or some other dimension of morality". ${ }^{77}$ The latter is of great importance to me: although principles form a part of the morality of duty, the substantive meaning of a principle lies closer to the morality of aspiration than is the case with concrete rules. This explains why principles form a beachhead within the morality of duty, reaching out towards the morality of aspiration. It also explains why a principle in a concrete case can yield to another principle, while retaining its significance. ${ }^{78}$

I agree with the critics of Dworkin's distinction, that rules do not always have an all or nothing character, and that often rules cannot easily be applied in a concrete case either, and that rules, just as principles, may conflict without harming the value of either of these rules. ${ }^{79}$ The basic difference between rules and principles lies in the higher moral character of principles and in their role as a link between ideals and legal rules. This difference in character has many implications for the meaning of principles in legal practice. One of the implications is that principles can only function and only have a meaning in 
connection with rules. The meaning of a legal principle even depends on the context of the rules, applicable in a given case.

When we take a closer look at the environmental legal principles that usually are to be found in international and national legal documents, a rough distinction can be made between principles of a more substantive nature and procedural principles. The precautionary principle and the "polluter pays" principle are examples of the first category. Principles on the access to information, participation in decision-making and access to justice are examples of the second category. Usually, procedural principles are less abstract than substantive ones, and therefore look more like rules. A good example is Principle 23 from the World Charter for Nature: ${ }^{80}$

All persons, in accordance with their national legislation, shall have the opportunity to participate, individually or with others, in the formulation of decisions of direct concern to their environment, and shall have access to means of redress when their environment has suffered damage or degradation.

Although of a more procedural nature, this principle is an important link between the ideal of sustainable development and concrete rules on access to decision-making processes and access to justice. As the WCED has shown, sustainable development is closely linked to the role of NGOs and private and community groups. ${ }^{81}$ Agenda 21 states:

One of the fundamental prerequisites ${ }^{82}$ for the achievement of sustainable development is broad public participation in decisionmaking. ${ }^{83}$

80 Adopted by the General Assembly of the UN on 29 October 1982 Doc A/37/L 4.

81 The need for information and participation of the public has also been stressed in the second report by the Club of Rome: King and Schneider First Global Revolution 73, 114, 246.

82 In his report on the application of the Rio Declaration, the Secretary-General cites this sentence using the word "principle" instead of "prerequisite", Rio Declaration on Environment and Development: Application and Implementation, Report of the SecretaryGeneral, Commission on Sustainable Development, Fifth session, 7-25 April 1997, UN Distr GEN E/CN 17/1997/8, 17.

83 UN Doc A/CONF151/26/Vol I-III, reprinted in Johnson Earth Summit 405 (par 23.2). 
One of the ideas in the concept of sustainable development is that the role of citizens in environmental policy must be recognized and strengthened, firstly, because the (potential) deterioration of man's environment may affect his individual environment in such a way that basic rights can no longer be exercised, ${ }^{84}$ and secondly, because interests that have no voice of their own are concerned, i.e. the interest of nature and of future generations. The ideal of sustainable development means that interests of future generations are not harmed by today's decisions or actions. To give these interests a voice, organisations and individuals can be given the opportunity to defend the interests of their descendants and of nature. Since this idea forms a basic part of the ideal of sustainable development, and because there is a lot of discussion going on considering the so-called anthropocentric character of the ideal of sustainable development, I will go into this matter more profoundly in paragraph 5.

\subsection{How do principles originate?}

I have stated that the high moral value of principles comes from an underlying ideal, using the example of sustainable development. But many of the now generally accepted principles of environmental law already existed before the ideal of sustainable development really became important internationally. Sands distinguishes between existing legal principles and new principles emerging in the context of sustainable development. ${ }^{85}$ An existing principle is, for instance, the principle of co-operation (essentially Principles 9 and 27 of the Rio Declaration, but also present in Principles 5, 7, 12, 13, 14 and 24), that was included in many other international environmental documents as well. The principle can be traced back as early as 1933 to the Convention Relative to the

84 Such as the right to privacy and family life, laid down in a 8 of the European Convention for the Protection of Human Rights and Fundamental Freedoms, Council of Europe http://conventions.coe.int 14 Feb. See, for instance, the famous case of López Ostra $v$. Spain of the European Court of Human Rights, December 9 1994, 1994 Human Rights LJ 444-447. For an overview of human rights involved in environmental degradation, see Churchill Environmental Rights 89-108.

85 Sands "International Law in the Field of Sustainable Development" 54. 
Preservation of Flora and Fauna in their Natural States. ${ }^{86}$ A relatively new principle is the precautionary principle that, at the international level, began to appear in the mid-1980s. ${ }^{87}$

This, however, does not mean that existing principles cannot have their roots in the ideal of sustainable development. Firstly, we have defined an ideal as a value that can be implicit in the law or the public and moral culture of a society. It is not farfetched to argue that the idea of sustainable development, however not explicitly formulated as such, ${ }^{88}$ was already on the (international) scene since World War II. ${ }^{89}$ Secondly, it can be argued that, since the break through of the ideal of sustainable development, the existing principles were strongly influenced by this ideal. Their meaning has not been the same since. An example is the co-operation principle, which, as shown above, already existed for a long time in international environmental law. Since the UNCED, the idea of co-operation is not only aimed at the prevention of environmental damage in neighbouring states (bilateral or regional), but at a much broader aim: sustainable development for the world community (global). ${ }^{90}$ This, among other things, means that developed states should make (technological) knowledge on environmental management available to developing countries, not as "aid", but as a common obligation or responsibility. ${ }^{91}$ Here we have a new meaning for an old principle.

86 Example given by Sands "International Law in the Field of Sustainable Development" 63.

87 Sands Principles of International Environmental Law 208.

88 The word "sustainable" was used sometimes in international agreements on the conservation of whales and seals, such as the 1957 Convention on Conservation of North Pacific Fur Seals, 314 UNTS 105. These conventions mainly aimed at securing future exploitation of these animals by man. A II (1) states: "In order to realize the objectives of this Convention, the Parties agree to coordinate necessary scientific research programs and to coordinate in investigating the fur seal resources of the North Pacific Ocean to determine: (a) what measures may be necessary to make possible the maximum sustainable productivity of the fur seal resources so that the fur seals populations can be brought to an maintained at the levels which will provide the greatest harvest year after year; and (b) [...]".Sands "International Law in the Field of Sustainable Development" 59 gives another example: the 1946 International Whaling Convention.

89 Sands "International Law in the Field of Sustainable Development" $306 \mathrm{ff}$ shows us that since 1946 there are many landmarks in the development of a more integrated economic, social and environmental approach in international law.

90 UN Dept for Policy Coordination and Sustainable Development, Report of the Expert Group Meeting on Identification of Principles of International Law for Sustainable Development, Background paper no. 3, New York 1996, 19 ff.

91 Porras Rio Declaration 28-29. 
But all this still gives no answer to the question in the title of this section. If a norm has all the characteristics of a principle, who then decides that this norm can be applied in the law as a principle? When we take environmental legal principles as an example, it is clear that it is mainly on the international level that most of the currently known principles have been initiated. Norms that have been included time after time in important international legal documents like treaties and declarations as "principles", can be considered to be legal principles. ${ }^{92}$ The same holds for norms that have been applied as principles by the courts according to legal precedent. One reference by a court to a norm as a "principle" does not yet make this norm a real principle. Generally, a norm slowly evolves to something that can be called a principle. ${ }^{93}$ There has to be a continuing reference by the courts to a norm before it can be called a principle. In both cases there has to be some durable practice in the (legal) community to make a norm a principle and a sense of appropriateness; ${ }^{94}$ even when a norm is first called a "principle", that norm might have been considered principal for a longer period of time already. It is not possible to create a principle by formulating a norm as such in a statute or in a judgement, as it is not possible to decide to change a principle. At a given point we notice that, because of a change of law or normative perception, a principle has acquired a somewhat different meaning. I already mentioned the example of the principle of cooperation.

\subsection{Conclusion: the ideal of sustainable development as the basis for legal principles of environmental law}

I can now answer my first question. The high moral value of principles comes from underlying ideals. An ideal is a value that is explicit, implicit or latent in the

92 I do not here wish to elaborate on the question whether these "environmental principles" can be seen as sources of international environmental law, such as "general legal principles" or "ius cogens" (A 38 of the Statute of the International Court of Justice).

93 MacCormick Legal Reasoning and Legal Theory 159.

94 Dworkin Model of Rules 40. This does not mean that everyone in the community has to agree on the content or on the importance of the moral value of the principle. 
law, or the public and moral culture of a society or group, that usually cannot be fully realised, and that partly transcends contingent, historical formulations, and implementations in terms of rules and principles. Since the explicit formulation of the ideal of sustainable development in 1987, principles of environmental law have been greatly influenced by this ideal. ${ }^{95}$ The aspiration of the ideal of sustainable development can only be promoted by concrete legal rules, by the morality of duty. Or, as Fuller puts it

...for workable standards of judgment the law must turn (however) to its blood cousin, the morality of duty. [...] what the morality of aspiration loses in direct relevance for the law, it gains in the pervasiveness of its implications. ${ }^{96}$

To bridge the gap between the highly abstract ideal and the very concrete substantive and procedural legal rules, legal principles of environmental law are a necessary link between the ideal of sustainable development and concrete environmental legislation.

\section{From principles to rules and policies}

My second question was: what is the exact difference between a principle and a legal rule, and between a principle and a policy goal? I will deal with the first half of the question in section 3.1, and with the second half of the question in section 3.2. Again, I will use the principles related to the ideal of sustainable development as the prime source of examples to illustrate my line of reasoning.

95 The question might arise whether legal principles have an influence on ideals: have existing legal principles influenced the meaning of the ideal of sustainable development as well? Such interaction is very well imaginable, especially now it is argued later in this article that principles not only influence more concrete legal rules, but that the application of these rules have an influence on the meaning of the principles as well.

96 Fuller Morality of Law 9. 


\subsection{Principles versus rules}

Dworkin has made a distinction between principles and rules. This distinction has been criticised by many, but, as stated above, can in general be upheld (cf section C). Principles differ from rules in the sense that rules can be more easily directly applied in individual cases, while principles give a general direction for a decision, with a much lesser required outcome, than would be the case with legal rules. It must be acknowledged that this difference is not a very strict one. There is a sliding scale with a theoretical abstract and indeterminate principle on one side and a very concrete, highly practical rule on the other. Both principles and rules can range from abstract to more concrete. Principles can become rules over time, when directly applicable in concrete cases. As already mentioned, the basic difference between rules and principles lies in the higher moral character of principles and in their role as a link between ideals and legal rules.

The higher moral character of principles forms the basis for their functions in legal practice. I distinguish nine functions, which are roughly sketched below.

1. Principles can enhance the normative power of statutory rules. Very often in environmental legislation, statutory rules are extremely open and mostly of a procedural nature, so that further guidance is desirable for all parties involved (those addressed by a rule and third parties, such as environmental organisations monitoring the company's behaviour). The rule that for a certain type of industry a permit is needed "in the interest of the environment" and that "negative effects for the environment must, as much as possible, be prevented or limited" is not very clear (examples taken from the Netherlands Environmental Management Act 1993). And the law that states, that in a specially protected area of natural beauty certain activities can only be carried out after a permit has been obtained, but that does not give any clue as to what criteria such a request must be tested against and under what conditions such a permit can be granted, acquires a greater normative power if principles are 
included in the statute itself, or if the rules in practice are influenced by unwritten principles.

2. Principles can help to define open or unclear statutory rules. This function follows from the first one and is aimed at administrative authorities and courts. Principles can be used by administrative authorities as well as the courts in the process of interpreting statutory rules in concrete cases, especially in cases where the rules are unclear or leave the competent authorities a great deal of room for discretion, or where there are conflicting rules.

3. Principles can increase legal certainty and enhance the legitimacy of decision-making. Because of the normative guidance offered by legal principles, both the administration and the judiciary are more or less obliged to motivate a decision in the light of the relevant principles, offering citizens more certainty as to what are important arguments for the decision and thus enhancing its legitimacy.

4. Principles form the basis for new statutory rules. Principles also give guidance to rulemakers, at national, European and international levels. They set the goals that have to be reached with (new) rules and thus create stability and legal certainty and they make sure that there is, to a certain extent, systematization of legal rules.

5. Principles give guidance to self-regulation and negotiation processes between various actors in society, such as NGOs, authorities and businesses, or otherwise help to determine how private parties should behave in the social order. In a time of a declining role for direct regulation and government intervention, and a growing call for deregulation and self-regulation, ${ }^{97}$ principles can give some guidance. Firstly, principles form a normative basis in negotiation processes among

97 Golub New Instruments 4 ff; Verschuuren "EC Environmental Law and Self-Regulation" 103-121. See also Communication from the Commission to the Council and the European Parliament on Environmental Agreements, 27 November 1996, COM(96) 561 final and the Commission Recommendation 96/733 of 9 December 1996 concerning Environmental Agreements implementing Community directives, 1996 Official Journal L333/59. 
social actors in decision-making processes of co-production and/or selfregulation (companies, local residents, environmental groups, governmental agencies). ${ }^{98}$ Secondly, when detailed rules are abolished in a deregulation programme, principles become more important to fill in or interpret the remaining (open) rules (see under 2). Sometimes the principles themselves are explicitly formulated in a process of selfregulation as well, like, for example, the Valdez Principles (drafted directly after the Exxon Valdez oil spill in Alaska in 1989, by a group of business people and investors). ${ }^{99}$

6. Principles create flexibility in the law. The sixth function is very much related to the fourth and fifth function. Since principles only point in a direction, without necessitating a specific outcome, principles are by their nature flexible norms. They make it possible for rulemakers to make less detailed rules and thus create more flexibility in the law. Principles offer the necessary beacons for such legislation.

7. Principles have to play an important role in national legal systems and in the EU, because they help to implement international obligations. In many important international legal documents, although not always legally binding, principles have been laid down as important guiding norms. To do justice to these principles, they must be seriously considered by nations that have signed international legal documents such as the Rio Declaration.

8. Principles stimulate integration of environmental considerations into other policy fields. Principles can also give guidance to decisions in other fields of policy that have an impact on the environment, such as decisions concerning transportation, energy, agriculture, and technology.

98 Sometimes called "shared decision-making", cf Williams, Penrose and Hawkes "Shared Decision-Making" 860. See for these "new" styles of decision-making Glasbergen (ed) Cooperative Environmental Governance.

99 The group called itself "Coalition for Environmentally Responsible Economies" (CERES). The Valdez Principles have been reprinted in an article on the subject: Anon 1990 Environmental Forum 35. The (new) CERES-principles can be found at the CERES http://www.ceres.org 14 Feb. 
In this way, they help to integrate environmental considerations into these other fields of policy.

9. Principles are necessary to pursue an ideal. Last but not least and already stated above, principles are a necessary link between ideals and concrete legal rules.

What is clear from these functions is the close relationship between principles and rules. Sands even states that "the substantive legal meaning of principles emerges only in their application to a given set of facts", ${ }^{100}$ and I think he is right. Rules and principles almost become one in the process of application of both of them. A rule is applied in the light of a relevant principle, and thus the principle influences the meaning of the rule. ${ }^{101}$ At the same time, the application of this rule (in the light of the relevant principle), gives the principle a clearer meaning than the principle has on its own: we see the relevance of a principle for legal practice especially when applying and interpreting rules in concrete cases or when making (new) rules.

Therefore, using principles by no means implies that we are not using rules. ${ }^{102}$ On the contrary, Sands states that, in the end, the influence of a principle on rules might even have become so strong, that it becomes a rule with a clear and unconditional content. ${ }^{103} \mathrm{His}$ example, the principle of sovereignty over natural resources and the responsibility not to cause damage to the environment of other states (Principle 2 of the Rio Declaration and Principle 21 of the Stockholm Declaration), however, is not convincing. The fact that this principle is the "cornerstone of international environmental law" and that it can be enforced before international courts and tribunals, ${ }^{104}$ does not mean that it has become a rule. The basic moral character of the principle remains intact,

100 Sands "International Law in the Field of Sustainable Development" 56.

101 "To attempt to [apply principles] in total disregard of all other considerations [...] edges over into fanaticism" according to McLoughlin and Bellinger Environmental Pollution Control 155.

102 As is stated by Lawson 1997 lowa Law Review 903.

103 Sands "International Law in the Field of Sustainable Development" 56.

104 Sands "International Law in the Field of Sustainable Development" 186-194. 
and the principle of sovereignty clearly has all the nine functions mentioned above. Although a legal principle can become very clear and unconditional in legal practice, it will still be considered as a principle and not as a rule. A principle, by its nature, keeps its specific functions, and therefore it is important to keep the basic difference between principles and rules in mind.

This goes for rules in various legal documents, such as acts and regulations, as well as transnational regulations, and selfregulatory rules. Principles thus are dynamic beacons in a wild ocean of ever changing concrete environmental rules. De Sadeleer stresses this special position of "directing principles": they can be an interface between modern and post-modern law, that is, between fixed standards and pragmatic and reversible rules. ${ }^{105}$

\subsection{Principles versus policies}

A third category distinguished by Dworkin, besides principles and rules, are policies. A policy, according to Dworkin, is "that kind of standard that sets out a goal to be reached, generally an improvement in some economic, political or social feature of the community", while a principle "is a standard to be observed, not because it will advance or secure an economic, political or social situation deemed desirable, but because it is a requirement of justice or fairness or some other dimension of morality." 106 To give an example in the field of environmental policy and law: the standard that in the Netherlands $\mathrm{CO}_{2}$ emissions in 2005 must have to be $5 \%$ below the level of 1990 is a policy goal. Such a goal may have been laid down in policy documents like policy plans or may just be a statement by the competent policy maker in the relevant democratic forum, for instance, the minister of the environment. Although not a principle or a rule in itself, such a policy goal does play a role in environmental law in two ways. First, legislation can determine that certain policy goals or policy statements have to be taken into account in a certain decision-making 
process. Secondly, a decision maker can be bound to his or her own policy on the basis of general principles of proper administrative action.

Still there remains a difference between rules and policies: rules have to be applicated directly. The policy goal on $\mathrm{CO}_{2}$ emissions mentioned above can be transformed in the directly applicable and enforceable rule that, in 2001, industry $\mathrm{X}$ will not be allowed to emit more $\mathrm{CO}_{2}$ than a total of 300,000 tonnes.

The difference between a policy and a principle might seem more problematic in practice, especially in a specific policy field like in that of the protection of the environment. Still, there are some big theoretical differences, which make it essential to differentiate between them. Principles are legal norms that, although not directly applicable (only via rules), have much more and a much more constant weight in legal practice. Principles have to be applied and cannot very easily be ignored because of their high moral content. When a relevant principle is passed over without good reason, a court will quash the decision. Policies have much less legal influence: a court will test a decision primarily against its accordance to binding legal principles and rules. Only in the two situations mentioned above (a statute explicitly obliged to take a certain policy document into account, or indirectly via the general principles of proper administrative action) policy documents can play a role in a judicial procedure against a government decision. In this case, however, it will be much easier for the government to give reasons acceptable to a court, not to follow the policy goal in a specific case. Also, policies may be changed overnight; principles, however, are embedded in the legal culture and, although their precise content may vary from time to time, principles remain relevant for a long period of time. Principles even have a strong influence on policies. It is not very well conceivable that a policy is announced that is contrary to certain principles of environmental policy and law. Principles thus influence not only the making and application of concrete rules, they also affect policies. When a State has adopted the "polluter pays" principle as a leading principle of environmental law, it will prove to be difficult for the competent authority to formulate a policy stating that, for the next five years, extra environmental taxes will be imposed on all people in order to raise funds to combat the consequences of 
acidification by the bio-industry. Such a policy will meet criticism in the political and social debate, but it will also be more difficult to implement in legal practice, since a decision implementing such policy would be contrary to the legal principle and might be quashed by the court.

\section{$4 \quad$ From ideals to rules and policies}

Policies do play an important part in the promotion of an ideal, such as the ideal of sustainable development, as do principles and rules. All are different standards necessary in our efforts to reach the ideal. Because of the different functions and the different legal meanings of these standards, I think it is crucial that in legal documents these differences are observed. It ís possible to formulate the ideal of sustainable development as a policy or a principle or as a rule, but this is not very practical. Following rule refers to the very abstract and vague notion of sustainable development, and therefore is not very useful; at least as far as the last few words are concerned: ${ }^{107}$

Member States shall draw up a list of zones and agglomerations in which the levels of pollutants are below the limit values. Member States shall maintain the levels of pollutants in these zones and agglomerations below the limit values and shall endeavour to preserve the best ambient air quality, compatible with sustainable development.

To focus on the ideal of sustainable development again, the entire structure of principles, rules and policies is as follows. To make the ideal of sustainable development more concrete and to have it implemented in concrete legal decisions, principles, such as the precautionary principle or the "polluter pays" principle, form a necessary link between the ideal, on one hand, and rules and policies, on the other. Both the formulation and the application of concrete legal rules are influenced by these principles. As far as abstract policies are concerned, ideals can more or less directly influence these (for instance, the policy of the minister of foreign aid to pay more attention to environmental 
issues when deciding on new aid programmes may be a consequence of the ideal of sustainable development). For the more concrete policies, this ideal is too abstract. In those cases, policies, like rules, are influenced by principles, but they also need enforceable legal rules in order to be achieved.

\section{From man to nature}

The ideal of sustainable development seems very anthropocentric: economic development of all nations, especially developing countries, must be stimulated, but the environment and natural resources may not be used in an unsustainable manner in order to preserve their potential use for future generations. With sustainable development, the ethical principles involved are about responsibilities among groups of human beings: developed versus developing and present versus future. ${ }^{108}$

Still, with sustainable development being an ideal of international environmental policy and law, which influences principles and environmental legal rules, the question arises of whether or not this is acceptable. Is the ideal really an anthropocentric ideal? If this is the case, it might be unacceptable that the legal principles and rules in the field of environmental law are being influenced by an anthropocentric ideal.

\subsection{Sustainable development: an anthropocentric ideal?}

It has generally been accepted that human interests cannot be separated from the protection of the environment. Protection of the environment because of human interests therefore has spill-over effects to non-humans (animals and nature). ${ }^{109}$ Even the 1946 International Convention for the Regulation of Whaling, which declares its purposes for the benefit of sustainable human 
exploitation, ${ }^{110}$ thus has a spill-over effect. But it must be acknowledged that this is not a very satisfactory approach to the issue of the aim of environmental policy and law in general and the aim of the ideal of sustainable development in particular.

Nature and the environment are entities worth moral consideration in their own right, not just because we need them for our survival or for our well-being. ${ }^{111}$ From this perspective one might ignore any reference to human interests or stewardship. This idea has been elaborated by some in the sense that, as natural objects have their own dignity, they should also be considered legal subjects, and have standing before the courts. Not just animals should be considered as legal entities possessing rights, ${ }^{112}$ but also mountains, rivers, plants, etc. ${ }^{113}$ These entities should be enabled, through guardians, to enforce their rights in courts for the benefit of the entities themselves.

I reject this approach. It has, quite acceptably, been argued that non-living entities, other than animals and possibly plants, cannot have interests of their own because they have no moral claim, ${ }^{114}$ which, for a matter of fact, does not necessarily mean that natural objects do not have an inherent value. ${ }^{115}$

If it cannot matter to canyon or trees if they are irreparably damaged, how are their guardians to know what to argue on their behalf, other than by using their own values ${ }^{116}$

We cannot exactly determine what is in the welfare of trees, rivers, habitats etc. The introduction of a limited amount of phosphates in a river disturbs the

110 Mentioned as an example of anthropocentric international environmental law by Boyle Role of International Human Rights Law 51.

111 This might even extend over inanimate nature, like rivers, rocks, Brennan Moral Standing of Natural Objects 35-54.

112 Cf, among many others, Regan Case for Animal Rights.

113 Besides the famous publication by Stone 1972 Southern California LR 450-501, the same thought has been put forward in German by, among many others, Bosselman 1986 Kritische Justiz 1-22 and Leimbacher Die Rechte der Natur.

114 Regan 1976 Philosophical Quarterly 253; Elder 1994 Osgoode Hall LJ 288.

115 Regan 1981 Environmental Ethics 30-31; Cahen 1988 Environmental Ethics 200, as reprinted in Brennan (ed) Ethics of the Environment 142.

116 Elder 1994 Osgoode Hall LJ 289. 
natural balance of the river, but on the other hand, it enriches plant and animal life in that same river. Now, what is in the best interest of the river? Also more practical questions remain unsolved: who should be appointed as a guardian, how must the guardian exercise the powers related to the rights of nature, what can the guardian do with the benefits of the exercise of these powers, etc?

These questions cannot be solved in our legal system. It is based on the social contract and it is especially meant to regulate human conduct in such a way that the exercise of certain fundamental liberties by all will be assured and that all will be provided with the necessary collective goods. The functions of constitutional and statutory law are aimed at people, with obligations and rights for people. Because of our attitude towards nature and the inherent value that we (human beings) consider nature and the environment to have, we can regulate our behaviour towards nature and the environment, but even then, the law deals with people alone.

The idea that nature has an inherent value cannot easily be found in UNCED documents on sustainable development. These documents represent rather anthropocentric views. Even the chapters of Agenda 21 aimed at protection of fragile ecosystems, such as wetlands, or at protection of biodiversity, have been written from the thought that natural entities have to be protected for man's own sake. They are our resources:

Biological resources feed and clothe us and provide housing, medicines and spiritual nourishment [...]. The current decline in biodiversity is largely the result of human activity and represents a serious threat to human development. ${ }^{117}$

The already mentioned first principle of the Rio Declaration states:

Human beings are at the centre of concerns for sustainable development. They are entitled to a healthy and productive life in harmony with nature. 
Some ecocentric elements can be found in the Convention on Biological Diversity, which also was concluded at the UNCED in $1992 .{ }^{118}$ The preamble starts as follows:

Conscious of the intrinsic value of biological diversity and the ecological, genetic, social, economic, scientific, educational cultural, recreational and aesthetic values of biological diversity and its components, [...].

However, Article 1 of the Convention, which lists the objectives of the Convention, has the familiar anthropocentric tone again:

The objectives of this Convention [...] are the conservation of biological diversity, the sustainable use of its components and the fair and equitable sharing of the benefits arising out of the utilization of genetic resources, including by appropriate access to genetic resources and by appropriate transfer of relevant technologies, taking into account all rights over those resources and to technologies, and by appropriate funding.

\subsection{Is an anthropocentric ideal acceptable?}

Although there has been a great deal of criticism on this anthropocentric tone in the UNCED documents, ${ }^{119}$ the ideal of sustainable development is not entirely incompatible with the idea that nature is worth protecting in its own right. True, the idea that nature and the environment are worth protecting, even when there is no human interest involved, cannot be found in any international documents on the ideal of sustainable development. However, this does not mean that it is not possible to keep the intrinsic value in focus while regulating human behaviour. Two lines of reasoning can be followed here.

Firstly, man is part of nature and cannot be separated from it. He depends on the existence of healthy and balanced ecosystems. Damaging the fragile balance of nature may be damaging to human beings as well. Man is 
dependent on ecosystems for the production of food, medicines, housing, and clothing. But:

...man does not live by food and fiber alone; he also needs a balanced $\mathrm{CO}_{2}-\mathrm{O}_{2}$ atmosphere, the climatic buffer provided by oceans and masses of vegetation, and clean (that is, unproductive) water for cultural and industrial uses. ${ }^{120}$

Since there still is a lot of uncertainty as to what the consequences of human actions are for the balance of ecosystems, for the conservation of biological diversity, for the climate system, a precautionary approach is advocated in the relevant international environmental law. ${ }^{121}$ This precautionary approach means that even when there is no conclusive evidence of harm to the environment, activities that could cause harm should be prohibited or should be bound by protective measures. ${ }^{122}$ Such an approach means that not just human interests in restricted sense must be considered, but all possible interests concerning nature and the environment, all of which might influence human existence.

If we extend the precautionary approach to future generations as well, the line of reasoning becomes even stronger. The extinction of species of plants or animals can limit the options of future generations, so sustainable development requires the conservation of plant and animal species, even if they are not of direct value to the life of present day man. ${ }^{123}$ To preserve these options for future generations, legal measures protecting the environment must be made by the present generation. ${ }^{124}$

The second argument can be that there is a moral relationship between man and nature. It has been argued that protecting nature is morally the best thing

120 Odum 1969 Science 164, reprinted in Nelissen, Van der Straaten and Klinkers (eds) Environmental Studies 135.

121 Hohmann Precautionary Legal Duties 341-345.

122 Backes and Verschuuren Precautionary Principle 58.

123 See WCED Our Common Future 46.

124 Brown Weiss 1990 AJIL 198-207. According to Brown Weiss, the legal implementation of the concept of protecting the environment for future generations is conducted along three lines: conservation of options, conservation of quality and conservation of access. 
to do: it is an "ideal of human excellence". ${ }^{125}$ This argument leads us back to the concept of ideals as elaborated above, ideals as values that are explicit, implicit or latent in the law, or the public and moral culture of a society or group that usually cannot be fully realised, and that partly transcend contingent, historical formulations, and implementations in terms of rules and principles.

It is not farfetched to suggest that there is a human ideal which the beetle crusher does not attain. Nor is it idle to suggest that a person who has been exposed to $B$ and reacted to $B$ the grandeur of great valleys or the majesty of mountains is better for it, than if he had passed the time playing pushpin. ${ }^{126}$

Often cited in this respect is also Kant:

A propensity to the bare destruction [...] of beautiful though lifeless things in nature is contrary to man's duty to himself. For such a propensity weakens or destroys that feeling in man [...] which [...] does much to promote a state of sensibility favorable to morals $[\ldots]^{127}$

Stone calls this "anthropocentric idealism", as opposed to other forms of idealism, among which "entity idealism", ${ }^{128}$ which suggests that the destruction of natural objects is wrong because the object is a good intrinsically: destruction is wrong irrespective of the consequences for the virtue or welfare of human beings. Contrary to Stone, I think it is safe to say that, because of the inherent value of natural objects, man has a duty to himself not to destroy this object. The (anthropocentric) ideal of human excellence therefore is closely linked to the idea that nature is intrinsically good: man can only reach this ideal when he realizes that nature has an inherent value. ${ }^{129}$

125 Terminology used by Cahen 1988 Environmental Ethics 215.

126 Stone 1985 Southern California LR 51.

127 Kant Metaphysical Principles of Virtue 105-106.

128 Stone 1985 Southern California LR 52.

129 The Aristotelian approach set out by O'Neill 1992 The Monist 132-133, reprinted in Brennan (ed) Ethics of the Environment 68. Although this approach takes into consideration the intrinsic value of non-human entities, it must be admitted that a greater preference or value, on the basis of species, is given to humans, which has been called a weaker form of human chauvinism: Routley and Routley Human Chauvinism 104. 
This moral relationship is reflected in the "last person on Earth scenario": the sole survivor on Earth of a nuclear war has the possibility, before dying, to push a button, destroying some surviving objects, like the Amazon rainforest, the last remaining herd of elephants or even non-natural objects with some intrinsic value like a painting by Van Gogh. It is morally wrong to do so because these objects have an intrinsic value and therefore not destroying them contributes to the virtue of man, to a flourishing human existence.

The best human life is one that includes an awareness of and practical concern with the goods of entities in the non-human world. [...] care for the natural world for its own sake is a part of the best life for humans $[\ldots]^{130}$

In both of the above interpretations, the seemingly anthropocentric ideal of sustainable development has a strong link to more ecocentric approaches of environmental law and policy. Environmental protection is necessary to achieve economic and moral goals of man, but in order to do so, all possible consequences for the environment must be considered carefully, thoroughly and precautiously, keeping in mind the intrinsic value of nature. This approach, however, does not entirely solve the problem that we cannot determine objectively how clean precisely a river must be.

Stone has argued to solve the latter problem by introducing an ideal-oriented construct:

[...] while we cannot orient the law to a Thing's welfare, we can orient it to some ideal state of the Thing, without [...] undertaking to express that ideal in a specific set of numbers. ${ }^{131}$

This interesting approach, which, although on a different level, has some of the characteristics of the concept of ideal-oriented environmental law as described above, can also be used in a more ecological approach of the ideal of sustainable development. 
In my view, to make sure that these ecological aspects of the ideal of sustainable development are sufficiently advanced in decision-making processes by governmental authorities and the courts, the principles that rule environmental decision-making processes must create enough room to take into account the more eco-centred arguments that can be found in all decisionmaking processes where environmental issues are at stake. Most of the environmental legal principles prevailing in international and national environmental law reflect this idea. The precautionary principle has already been mentioned as an example. Legal rules that are influenced by the precautionary principle must compel the government to constantly review its policy in the light of the interests of future generations and the environment (and to make laws that guarantee such a review), and to assess the impact administrative decisions may have on the quality of the environment, including the intrinsic value of natural objects. Legislators may even explicitly state that when exercising certain powers, the competent authorities must act according to the principle that "the intrinsic value of animals is recognized". ${ }^{132}$

Another example is the "polluter pays" principle, which is not only relevant to damage to a person or a person's possessions, but also to damage to natural objects with no direct economic relevance, like Alaska's Prince William Sound, where in 1989 oil from the Exxon Valdez spoiled a great deal of the then present natural objects.

Procedural principles like the principles of participation in decision-making processes and access to justice in environmental matters for interested parties also play an important part in realising the ideal of sustainable development in the broad sense, mentioned above, as illustrated by the 1998 Convention on Access to Information, Public Participation in Decision-Making and Access to 
Justice in Environmental Matters. ${ }^{133}$ The government has to pursue an open kind of decision-making when the environment is concerned. Participation of citizens and the possibility of judicial review are essential when deciding on environmental matters or on other matters which may have consequences for the quality of the environment. ${ }^{134}$ Exceptions to this rule cannot very easily be justified, at least not in this approach of environmental constitutional democracy: everyone has a responsibility towards (voiceless) future generations and natural objects, and everyone must at least be able to fulfil this responsibility, in order to promote the ideal of "human excellence".

\section{Conclusion}

Principles of environmental law receive their high moral value from underlying ideals, most notably the ideal of sustainable development. An ideal is a value that is explicit, implicit or latent in the law, or the public and moral culture of a society or group that usually cannot be fully realized, and that partly transcends contingent, historical formulations, and implementations in terms of rules and principles. The ideal of sustainable development has been explicitly laid down in many international, European and national legal documents, both of a binding and a non-binding nature. The ideal strongly influences existing and new principles of environmental law, and, through the principles, also more concrete legal rules and policies.

133 UN Distr Gen ECE/CEP/43, 21 April 1998, reprinted in 1999 ILM 517. The preambular paragraphs of this Convention recognise "that every person has the right to live in an environment adequate to his or her health and well-being, and the duty, both individually and in association with others, to protect and improve the environment for the benefit of present and future generations," and consider "that, to be able to assert this right and observe this duty, citizens must have access to information, be entitled to participate in decision-making and have access to justice in environmental matters, and acknowledging in this regard that citizens may need assistance in order to exercise their rights [...]".

134 This has explicitly and unmistakably been recognised in international environmental law with the adoption of the Convention on Access to Information, Public Participation in Decision-Making and Access to Justice in Environmental Matters in 1998, of which the first article reads as follows: "In order to contribute to the protection of the right of every person of present and future generations to live in an environment adequate to his or her health and well-being, each Party shall guarantee the rights of access to information, public participation in decision-making, and access to justice in environmental matters in accordance with the provisions of this Convention" 1999 ILM 517. 
Principles form a necessary link between directly applicable and enforceable environmental legal rules and the underlying ideal. They are a necessary medium for ideals to find their way into concrete statutory and treaty rules and standards and can be used to bridge the gap between the morality of duty and the morality of aspiration. Because of their basis in (written or unwritten) law and their possible direct and intense influence on legal rules concerning activities that may harm the environment, they must be placed within the morality of duty: a bridgehead within the morality of duty reaching out for the morality of aspiration. From the general function of principles of forming a beachhead in the morality of duty, nine more concrete functions can be derived. These functions principles, both of a substantive and of a procedural nature, have, make it possible to distinguish them from legal rules. It must be acknowledged, however, that there is no very strict separation between principles on one side and rules on the other: environmental norms can be placed on a sliding scale with rules on one side and principles on the other side. Principles can become rules over time, when directly applicable in concrete cases.

The nine functions are following:

1. principles can enhance the normative power of statutory rules;

2. principles can help to fill in open or unclear statutory rules;

3. principles can increase legal certainty and enhance the legitimacy of decision-making;

4. principles form the basis for new statutory rules;

5. principles give guidance to self-regulation;

6. principles create flexibility in the law;

7. principles help to implement international obligations;

8. principles stimulate integration of environmental considerations into other policy fields;

9. principles are necessary to pursue an ideal.

Principles thus influence the meaning of a rule but, at the same time, the application of a rule in a concrete case gives the relevant principle a clearer meaning than the principle has on its own. This goes for rules in various legal 
documents, such as acts and regulations, as well as trans-national regulations, and self regulatory rules. Principles thus are dynamic beacons in a wild ocean of ever changing concrete environmental rules.

Although the underlying ideal of sustainable development has a rather anthropocentric character, the danger of influencing environmental legal principles (and through principles legal rules and policies as well) in a highly anthropocentric way is small. Firstly, because man is an inseparable part of nature and is very much dependent on balanced and intact ecosystems, especially when future generations are considered as well. Secondly, there is a moral relationship between man and nature. Natural objects have an inherent value: not destroying these objects contributes to the virtue of man.

The ecological aspects of the ideal of sustainable development can be sufficiently advanced in decision-making processes by governmental authorities and courts, because most principles that rule environmental decision-making processes create enough room to take into account the more eco-centred arguments. 


\section{Bibliography}

Alexy Zum Begriff des Rechtsprinzips 81

Alexy R "Zum Begriff des Rechtsprinzips" in Krawietz W et al (eds)

Rechtstheorie - Beiheft 1 Argumentation und Hermeneutik in der

Jurisprudenz (Duncker und Humblot Berlin 1979) 59-87

Anon 1990 Environmental Forum 35

Anon "Can the Valdez Principles Green Corporate America?" 1990

Environmental Forum 35

Backes and Verschuuren 1998 Colorado J of International Environmental Law and Policy 58

Backes CW and Verschuuren JM "The Precautionary Principle in International, European, and Dutch Wildlife Law" 1998 Colorado J of International Environmental Law and Policy 58

Bocken and Ryckbost (eds) Codification of Environmental Law 161-163 Bocken $\mathrm{H}$ and Ryckbost D (eds) Codification of Environmental Law (Kluwer London 1996)

Bodansky 1993 Yale J of International Law 501-502

Bodansky D "The United Nations Framework on Climate Change: A

Commentary" 1993 Yale J of International Law 451-588

Bodnarek Concept of Sustainable Development 102-106

Bodnarek RK The Concept of Sustainable Development and its Implications for Environmental Law (Dalhousie University Halifax 1993)

Bosselman 1986 Kritische Justiz 1-22

Bosselman K "Eigene Rechte für die Natur?" 1986 Kritische Justiz 1-22

Boyle Role of International Human Rights Law 51

Boyle AE "The Role of International Human Rights Law in the Protection of 
the Environment" in Boyle AE and Anderson MR (eds) Human Rights Approaches to Environmental Protection (Oxford University Press Oxford 1996) $43-70$

Breidenich et al 1998 AJIL 324-325

Breidenich C et al "The Kyoto Protocol to the United Nations Framework Convention on Climate Change" 1998 AJIL 315-331

Brennan (ed) Ethics of the Environment 142

Brennan A (ed) The Ethics of the Environment (Dartmouth Aldershot 1995)

Brennan Moral Standing of Natural Objects 35-54

Brennan A "The Moral Standing of Natural Objects" in: Brennan A (ed) The Ethics of the Environment (Dartmouth Aldershot 1995) 35-54

Brown Weiss 1990 AJIL 198-207

Brown Weiss E "Our Rights and Obligations to Future Generations for the Environment" 1990 AJIL 198-207

Cahen 1988 Environmental Ethics 200

Cahen H "Against the Moral Considerability of Ecosystems" 1988 Environmental Ethics 200

Cans 1995 Revue Juridique de l'Environnement 195-217

Cans C "Grande et petite histoire des principes généraux du droit de l'environnement dans la loi du 2 février 1995" 1995 Revue Juridique de l'Environnement 195-217

Churchill Environmental Rights 89-108

Churchill R "Environmental Rights in Existing Human Rights Treaties" in Boyle AE and Anderson MR (eds) Human Rights Approaches to Environmental Protection (Oxford University Press Oxford 1996) 89-108 
Craven 1998 RECIEL 1-95

Craven M "Human Rights and the Environment: The Case of BalmerSchafroth and Others v Switzerland" 1998 RECIEL 1-95

De Sadeleer Environmental Principles

De Sadeleer N Environmental Principles: From Political Slogans to Legal Rules (Oxford University Press Oxford 2002)

Dworkin Model of Rules I

Dworkin R "The Model of Rules I" in Taking Rights Seriously (Duckworth London 1996)

Elder 1994 Osgoode Hall LJ 288

Elder PS "Legal Rights for Nature: The Wrong Answer to the Right(s) Question" 1994 Osgoode Hall LJ 288

Experts Group on Environmental Law Environmental Protection

Experts Group on Environmental Law of the WCED Environmental

Protection and Sustainable Development: Legal Principles and

Recommendations (Graham and Trotman London 1987)

Fisher and Harding Precautionary Principle in Australia 215-233

Fisher E and Harding R "The Precautionary Principle in Australia: From Aspiration to Practice?" in O'Riordan T, Cameron J and Jordan A (eds) Reinterpreting the Precautionary Principle (Cameron May London 2000) 215-233.

Fuller Morality of Law 5

Fuller LL The Morality of Law Rev ed (Yale University Press London 1974)

Glasbergen (ed) Co-operative Environmental Governance

Glasbergen P (ed) Co-operative Environmental Governance (Kluwer London 1998) 
Goldsmith 1972 The Ecologist 1-22

Goldsmith E et al "A Blueprint for Survival" 1972 The Ecologist 1-22 Reprint in Nelissen N, Van der Straaten J and Klinkers L (eds) Classics in Environmental Studies (International books Utrecht 1997) 199-210

Golub New Instruments 4

Golub J "New Instruments for Environmental Policy in the EU: Introduction and overview" in New Instruments for Environmental Policy in the EU (Routledge London 1998) 1-29

Hohmann Precautionary Legal Duties 341-345 Hohmann H Precautionary Legal Duties and Principles of Modern International Law, The Precautionary Principle: International Environmental Law Between Exploitation and Protection (Graham \& Trotman London 1994) $341-345$

Jégouzo 1995 RFD adm 12(2) 209-217

Jégouzo $Y$ "Les principes généraux du droit de l'environnement" RFD adm. 12(2) $209-217$

Johnson Earth Summit 129

Johnson SA The Earth Summit The United Nations Conference on Environment and Development (UNCED) (Graham \& Trotman London 1993)

Kant Metaphysical Principles of Virtue 105-106

Kant I The Metaphysical Principles of Virtue (translated from the original German by J Ellington (Bobbs-Merrill Indianapolis 1964)

Kidd 1992 Journal of Agricultural \& Environmental Ethics 1-26

Kidd CV "Evolution of Sustainability" 1992 Journal of Agricultural \& Environmental Ethics 1-26 
King and Schneider First Global Revolution 73, 114, 246

King A and Schneider B The First Global Revolution (Pantheon Book New York 1991)

Lawson 1997 lowa Law Review 893-903

Lawson G "A Farewell to Principles" 1997 Iowa Law Review 893-903

Leimbacher Die Rechte der Natur

Leimbacher J Die Rechte der Natur (Helbing \& Lichtenberg Basel 1988)

MacCormick 1974 Law Quarterly Rev 127

MacCormick N "Law as Institutional Fact" 1974 Law Quarterly Rev 102-129

MacCormick Legal Reasoning and Legal Theory 159

MacCormick N Legal Reasoning and Legal Theory (Clarendon Oxford 1978) 159

Mann "Comment on the Paper by Philippe Sands" 67-72

Mann $\mathrm{H}$ "Comment on the Paper by Philippe Sands" in Lang W (ed)

Sustainable Development and International Law (Graham and Trotman London 1995) 67-72

McLoughlin and Bellinger Environmental Pollution Control 155 McLoughlin J and Bellinger EG, Environmental Pollution Control (Graham and Trotman London 1993)

Nelissen, Van der Straaten and Klinkers (eds) Environmental Studies 135 Nelissen N, Van der Straaten J and Klinkers L (eds) Classics in Environmental Studies (International books Utrecht 1997) 135

Nollkaemper Legal Regime for Transboundary Water Pollution 82 Nollkaemper A The Legal Regime for Transboundary Water Pollution: Between Discretion and Constraint (Graham and Trotman Dordrecht 1993) 
O'Neill 1992 The Monist 132-133

O'Neill J "The Varieties of Intrinsic Value" 1992 The Monist 132-133

Odum 1969 Science 164

Odum EP "The Strategy of Ecosystem Development, An Understanding of Ecological Succession Provides a Basis for Resolving Man's Conflict with Nature" 1969 Science 164

Pallemaerts International Environmental Law 12-13

Pallemaerts M "International Environmental Law from Stockholm to Rio:

Back to the Future?" in Sands P (ed) Greening International Law (Earthscan London 1993) 1-19

Porras Rio Declaration 33

Porras IM "The Rio Declaration: a New Basis for International Cooperation" in Sands P (ed) Greening International Law (Earthscan London 1993) 2033

Raz 1972 Yale LJ 823

Raz J "Legal Principles and the Limits of Law" 1972 Yale LJ 823-854

Redgwell Life, the Universe and Everything 87

Redgwell C "Life, the Universe and Everything: A Critique of Anthropocentric Rights" in Boyle AE and Anderson MR (eds) Human Rights Approaches to Environmental Protection (Oxford University Press Oxford 1996) 87

Regan 1976 Philosophical Quarterly 253

Regan T "McCloskey on Why Animals cannot have Rights" 1976 Philosophical Quarterly 253

Regan Case for Animal Rights

Regan T The Case for Animal Rights (Routledge London 1983) 
Regan 1981 Environmental Ethics 30-31

Regan T "The Nature and Possibility of an Environmental Ethic" 1981 Environmental Ethics 19-34

Routley and Routley Human Chauvinism 104

Routley R and Routley V "Against the Inevitability of Human Chauvinism" reprinted in Elliot R (ed) Environmental Ethics (Oxford University Press Oxford 1995) 104-128

Sands "International Law in the Field of Sustainable Development" 303-381 Sands P 1994 "International Law in the Field of Sustainable Development" in British Year Book of International Law (Hodder and Stoughton London 1994) 303-381

Sands "International Law in the Field of Sustainable Development" 54 Sands P "International Law in the Field of Sustainable Development: Emerging Legal Principles" in Lang W (ed) Sustainable Development and International Law (Graham \& Trotman London 1995) 53-66

Sands Principles of International Environmental Law 208 Sands P Principles of International Environmental Law I, Frameworks, Standards and Implementation (Manchester University Press Manchester 1994)

Scholten Rechtsbeginselen 270

Scholten P Rechtsbeginselen 2nd ed (Tjeenk Willink Zwolle 1941)

Schröder Sustainable Development and Law 5

Schröder M Sustainable Development and Law (Tjeenk Willink Zwolle 1996)

Selznick Moral Commonwealth 438

Selznick P The Moral Commonwealth, Social Theory and the Promise of Community (UC Press Berkeley 1992) 
Sendler 1996 Neue Zeitschrift für Verwaltungsrecht 1145-1151

Sendler H "Stand der Überlegungen zum Umweltgesetzbuch" 1996 Neue Zeitschrift für Verwaltungsrecht 1145-1151

Shue 1995 International Affairs 458

Shue $\mathrm{H}$ "Ethics, the Environment and the Changing International Order" 1995 International Affairs 458

Stone 1972 Southern California LR 450-501

Stone CD "Should trees have standing? Toward Legal Rights for Natural Objects" 1972 Southern California LR 450-501

Stone 1985 Southern California LR 51

Stone CD "'Should trees have standing?' Revisited: How Far Will Law and Morals Reach? A Pluralistic Perspective" 1985 Southern California LR 1154

Stone Nonperson in Law 49-64

Stone CD "The Nonperson in Law" in Should Trees Have Standing? And other essays on law, morals and the environment (Oceana Dobbs Ferry 1997) $49-64$

Taekema Concept of Ideals in Legal Theory 11

Taekema S The Concept of Ideals in Legal Theory (Tilburg University Tilburg 2000)

Van der Burg 1997 Journal of Value Inquiry 25

Van der Burg W "The Importance of Ideals" 1997 Journal of Value Inquiry 23-37

Van der Burg Morality of Aspiration 167-192

Van der Burg W "The Morality of Aspiration: A Neglected Dimension of Law 
and Morality" in Witteveen WJ and Van der Burg W (eds) Rediscovering Fuller (Amsterdam University Press Amsterdam 1999)

Verschuuren "EC Environmental Law and Self-Regulation" 103-121

Verschuuren J 2000 "EC Environmental Law and Self-Regulation in the Member States: in Search of a Legislatory Framework" Yearbook of European Environmental Law (Oxford University Press Oxford) 103-121

Verschuuren Principles of Environmental Law 109-128

Verschuuren J Principles of Environmental Law (Nomos Baden Baden 2003) $109-128$

Verschuuren and Oudenaarden The Role of Ideals 231-262

Verschuuren $\mathrm{J}$ and Oudenaarden $\mathrm{T}$ "The Role of Ideals in Legal Development: Sustainable Development and the Conservation of Biodiversity as Cases in Point" in Van der Burg W and Taekema S (eds) The Importance of Ideals: Debating Their Relevance in Law, Morality, and Politics Series Philosophy and Politics 10 (Peter Lang Brussels 2004) 231262

Vranken Algemeen Deel 86

Vranken JBM Algemeen Deel (Tjeenk Willink Zwolle 1995)

Williams, Penrose and Hawkes "Shared Decision-Making" 860

Williams PW, Penrose RW and Hawkes S, "Shared Decision-Making in Tourism Land Use Planning" Annals of Tourism Research (Pergamon New York 1998) 860

WCED Our Common Future

World Commission on Environment and Development Our Common Future (Oxford University Press Oxford 1987) 


\section{Register of legislation}

Belgian Act on Environmental Policy 1995

Dutch Experiments on Animals Act 1997

Environment and Biodiversity Conservation Act 91 of 1999

Japanese Basic Environmental Law 91 of 1993

Netherlands Environmental Management Act 1993

\section{Register of cases}

Case concerning the Gabcikovo-Nagymaros Project 199837 ILM 162

Balmer-Schafroth v Switzerland ECHR 26 August 1997 Rep 1997-IV

\section{Treaties and other international sources}

Convention for the Protection of the Marine Environment of the North East Atlantic 1992

Convention on Access to Information, Public Participation in Decision-Making and Access to Justice in Environmental Matters 1998

Convention on Conservation of North Pacific Fur Seals 1957

Helsinki Convention on the Protection and Use of Transboundary Watercourses and International Lakes 1992

Rio Declaration on Environment and Development 1992

Rio Declaration on Environment and Development 1992

Stockholm Declaration on the Human Environment 1972

Treaty of Amsterdam 1997

\section{Register of Internet resources}

CERES http://www.ceres.org 14 Feb

CERES Coalition for Environmentally Responsible Economies [Found on Internet] http://www.ceres.org [Date of use 14 Feb 2006]

Council of Europe http://conventions.coe.int 14 Feb

Council of Europe 1950 European Convention for the Protection of Human Rights and Fundamental Freedoms, ETS No 5 [Found on Internet] http://conventions.coe.int [Date of use 14 Feb 2006] 
CURIA http://curia.eu.int $18 \mathrm{Apr}$

Court of Justice of the European Communities [Found on Internet] http://curia.eu.int [Date of use 18 Apr 2006]

Earth Charter Commission http://www.earthcharter.org 14 Feb

Earth Charter Commission [Found on Internet] http://www.earthcharter.org [Date of use 14 Feb 2006]

IUCN http://iucn.org/themes/law/cel07.html 14 Feb

IUCN 1990-1996 Draft International Covenant on Environment and

Development [Found on Internet] http://iucn.org/themes/law/cel07.html

[Date of use 14 Feb 2006] 